\title{
Kaji Pengaruh Penggunaan Tipe Busi Terhadap Kinerja Sepeda Motor Sebagai Sarana Transportasi
}

\author{
S.J.E. Sarwuna ${ }^{1, *}$, W.M.E. Wattimena ${ }^{2}$ dan, C.S.E. Tupamahu ${ }^{3}$ \\ ${ }^{1}$ Jurusan Teknik Mesin Fakultas Teknik Universitas Pattimura, Ambon 97233 \\ *sefnath.sarwuna@fatek.unpatti.ac.id \\ 2Jurusan Studi Teknik Mesin Universitas Pattimura \\ Email :WMEWattimena273@gmail.com \\ 3Jurusan Studi Teknik Mesin Universitas Pattimura \\ Email : cendy.tupamahu@fatek.unpatti.ac.id
}

\begin{abstract}
Abstrak. Busi merupakan salah satu komponen dalam system pengapian berperan sebagai penghasil api. Busi terdiri dari berbagai varian yang dalam penggunannya membakar campuran udara dan bahan bakar dalam ruang yang kemudian memberikan pengaruh terhadap peningkatan maupun penuruan kinerja dari mesin. Untuk itu penelitian ini bertujuan untuk mengetahui pengaruh penggunaan tipe busi terhadap kinerja sepeda motor empat langkah $135 \mathrm{cc}$. Metode penelitian dilakukan dengan pendekatan eksperimental menggunakan kendaraan Jupiter MX 135 cc, pengujian dilakukan secara statis dengan menggunakan alat bantu dynamometer type prony brake. Data yang diukur berupa putaran di poros engkol dan putaran dari prony brake pada berbagai variasi beban prony sebesar $3 \mathrm{~kg}, 4 \mathrm{~kg}, 5 \mathrm{~kg}$ dan $6 \mathrm{~kg}$ (beban diletakan pada pedal rem cakram belakang) yang kemudian dikonversikan ke dalam satuan Newton untuk dua tipe busi masing - masing yakni busi standar dan busi platinum. Berdasarkan data-data tersebut dihitung torsi pada prony brake, torsi motor, dan daya efektif. Hasil penelitian menunjukan bahwa torsi maksimum dan daya maksimum kendaraan untuk penggunaan busi standar dicapai pada reduction gear 4 sebesar 10,74 $\mathrm{Nm}$ dan 5813,11 W dibandingkan dengan reduction gear 1, 2 dan 3. Begitu juga dengan tipe busi Platinum menghasilkan torsi maksimum dan daya maksimum pada reduction gear 4 sebesar 8,24 Nm dan 4684,22 W lebih rendah dibandingkan busi Standar. Dari hasil pengujian dapat dilihat busi platinum harus digunakan pada kendaraan yang mengutamakan kecepatan tinggi namun hanya menerima sedikit pembebanan (torsi kecil) sedangkan busi lebih di khususkan pada kendaraan harian yang mengutamakan torsi yang besar namun tidak membutuhkan kecepatan tinggi.
\end{abstract}

Kata Kunci: dynamometer Prony brake, Tipe busi, Kinerja Mesin Sepeda Motor

\begin{abstract}
Spark plugs are one of the components in the ignition system's role as a fire producer. Spark plugs consist of various variants which in their use burns a mixture of air and fuel in a chamber which then has an effect on improving and reducing the performance of the engine. For this reason, this study aims to determine the effect of using the type of spark plug on the performance of a 135cc four-step motorcycle. The research method was conducted with an experimental approach using a Jupiter MX 135 cc vehicle, testing was carried out statically using a dynamometer prony brake type tool. Data measured in the form of rotation on the crankshaft and rotation of the prony brake at various prony load variations of $3 \mathrm{~kg}, 4 \mathrm{~kg}, 5 \mathrm{~kg}$ and $6 \mathrm{~kg}$ (the load is placed on the rear disc brake pedal) which is then converted into Newton units for two types of spark plugs respectively namely standard spark plugs and platinum spark plugs. Based on these data torque is calculated on prony brakes, motor torque, and effective power. The results showed that the maximum torque and maximum power of vehicles for the use of standard spark plugs were achieved in reduction gear 4 of $10.74 \mathrm{Nm}$ and $5813.11 \mathrm{~W}$ compared to reduction gear 1, 2 and 3. Likewise with the type of Platinum spark plugs produce maximum torque and power the maximum reduction in gear 4 is $8.24 \mathrm{Nm}$ and $4684.22 \mathrm{~W}$ lower than the Standard spark plug. From the test results it can be seen that platinum spark plugs should be used in vehicles that prioritize high speeds but only receive a small amount of load (small torque) while spark plugs are more specialized in daily vehicles that prioritize large torque but do not require high speeds.
\end{abstract}

Key Word: dynamometer prony brake, spark plug, Vehicle Performance

\section{PENDAHULUAN}

Kendaraan roda dua di era globalisasi dijadikan sebagai objek persaingan bagi hamper semua produsen kendaraan khususnya roda dua. Persaingan untuk menyajikan kendaraan dengan performa yang lebih baik, dalam hal daya mesin yang besar, torsi yang besar namun didukung dengan penggunaan bahan bakar yang lebih efisien. Salah satu usaha untuk meningkatkan performa yang dimaksud bisa 
kita lihat dari system pengapian kendaraan. Lebih khusunya komponen pendukung yang disebut dengan Busi yang berfungsi sebagai penghasil percikan api untuk membakar campuran bahan bakar dan udara khususnya pada motor bensin. Pengaruh penggunaan busi standar dan busi racing terhadap daya sebesar 9,6PS pada tekanan kompresi 14,1 $\mathrm{kg} / \mathrm{cm}^{3}$ pada putaran $8000 \mathrm{rpm}$, Tosi maksimum sebesar 9,4 Nm dan tekanan kompresi sebesar 13 $\mathrm{kg} / \mathrm{cm}^{3}$ pada putaran $6000 \mathrm{rpm}$ sedangkan kosumsi bahan bakar mengalami penurunan [3]. Pemakaian busi elektroda Platinum dan Iridium dibandingkan dengan busi elektroda Nikel pada putaran 7000 $9000 \mathrm{rpm}$ memberikan kenaikan torsi, daya, dan efisiensi thermal masing-masing sebesar $4,84 \%$, $6,43 \%, 6,43 \%$ dan $6,08 \%$ (untuk busi elektroda Platinum) dan $8,42 \%, 12,02 \%, 12,02 \%$ dan $13,10 \%$ (untuk busi elektroda Iridium). Penelitian ini menggunakan metode true experiment dilaboratorium dengan dua tipe busi sebagai pembanding terhadap busi elektroda nikel, penelitian menggunakan motor bensin 4 langkah 1 silinder Supra X-125cc dengan variasi putaran [10]. Torsi tertinggi didapat pada busi Iridium yang mencapai 8,75 Nm pada putaran $5069 \mathrm{rpm}$, Daya tertinggi dihasilkan pada busi Iridium disbanding busi kaki dua mencapai 8,1 Hp pada putaran 7692 rpm dan konsumsi bahan bakar terendah didapat pada busi Iridium sebesar $0,078 \mathrm{~kg} / \mathrm{h} . \mathrm{Hp}$ pada putaran $6000 \mathrm{rpm}$. Penelitian menggunakan sepeda motor Yamaha Jupiter Z, pengujian unjuk kerja menggunakan dynotest (Sportdyno V3.3). dilakukan secara bergantian untuk masing-masing busi dan variasi putaran 4000 - $10000 \mathrm{rpm}$ [4]. Hasil penelitian menunjukan bahwa busi dingin Denso U24EPR9 dapat menurunkan konsumsi bahan bakar pada putaran $1700 \mathrm{rpm}$ sebesar $0,1173 \mathrm{~kg} / \mathrm{jam}$, putaran $1900 \mathrm{rpm}$ sebesar $0,1187 \mathrm{~kg} / \mathrm{jam}$, putaran $2100 \mathrm{rpm}$ sebesar $0,1261 \mathrm{~kg} / \mathrm{jam}$. Sedangkan penggunaan busi panas Champion RG4HC meningkatkan konsumsi bahan bakar pada putaran $1700 \mathrm{rpm}$ sebesar 0,1407 kg/jam, $1900 \mathrm{rpm}$ sebesar $0,1554 \mathrm{~kg} / \mathrm{jam}$ dan $2100 \mathrm{rpm}$ sebesar 0,1935 kg/jam. Penelitian dilakukan secara eksperimental di laboratorium menggunakan dua tipe busi, pengujian tiap sampel busi dilakukan dengan putaran mesin yang berbeda - beda. Alat penelitian menggunakan Honda Beat tahun 2012 [1]. Celah busi 0,4 mm, dengan variasi jenis busi standar, platinum dan iridium terhadap emisi $\mathrm{CO}$ dan $\mathrm{HC}$, dimana nilai terendah $\mathrm{CO}$ 0,27\% dan $\mathrm{HC} 98$ ppm, celah busi 0,5 mm dimana nilai terendah $\mathrm{CO} 0,15 \%$ dan $\mathrm{HC} 45$ ppm, celah busi $0,6 \mathrm{~mm}$ nilai terendah $\mathrm{CO} 0,19 \%$ dan $\mathrm{HC} 24 \mathrm{ppm}$. Alat penelitian menggunakan Motor Honda Revo 110 cc, Penelitian ini dilakukan dengan pengujian variasi celah busi ukuran $0,4-0,6$ mm kemudian varias terhadap emisi $\mathrm{CO}$ dan $\mathrm{HC}$ yang dilakukan dengan uni Engine Gas Analyzer untuk mendapatkan data $\mathrm{CO}$ dan $\mathrm{HC}$ [7]. Pengaruh jarak keregangan celah elektroda busi terendah pada jarak celah busi standar ( $0,70 \mathrm{~mm})$ dengan persentase penuruan kadar emisi gas buang $\mathrm{CO}$ terendah yaitu sebesar $0,543 \%$ sedangkan untuk kadar HC yang paling rendah 39,11 ppm. Penelitian menggunakan sepeda motor Yamaha Byson. Pengujian gas buang CO dan HC dilakukan pada masing-masing putaran mesin sebanyak tiga kali dengan rpm 1500, 2500 dan 3500 berbeda-beda dengan alat uji Four Gas Analyzer [9]. Penggunaan buai berdasarkan tingkar panas pda sepeda motor Honda Revo Fit 110cc tahun 2012 berpengaruh terhadap konsumsi bahan bakar. Pada penggunaan busi U20EPR9 konsumsi bahan bakar pada semua putaran diujikan adalah $82,27 \mathrm{ml}$, sedangkan konsumsi bahan bakar busi U24EPR9 adalah 80,98 $\mathrm{ml}$ mengalami penurunan $1,5 \%$. Pada pemakaian busi U27EPR9 konsumsi bahan bakar adalah 72,68 $\mathrm{ml}$ mengalami penurunan $11,6 \%$ dari busi U20EPR9. Konsentrasi Karbon Monoksida terendah dihasilkan ooleh busi U27EPR9 pada putaran 1500 rpm sebesar $0,12 \%$. Konsentrasi Karbondioksida tertinggi dihasilkan oleh busi U27EPR9 pada putaran $4000 \mathrm{rpm}$ sebesar $1,27 \%$. Konsentrasi Hidrokarbon terendah dihasilkan oleh busi U20EPR9 pada putaran $4000 \mathrm{rpm}$ sebesar 16,29 ppm. Sedangkan konsentrasi Oksigen mengalami peningkatan yang signifikan pada penggunaan busi U20EPR9, peningkatan tertinggi sebesar $19,70 \%$ didapatkan pada putaran $4000 \mathrm{rpm}$. Jenis penelitian statistic inferensia. Metode ini membahas mengenai cara menganalisis data serta mengambil kesimpulan. Metode ini berkaitan dengan analisis sebagian data sampai ke peramalan atau penarikan kesimpulan mengenai keseluruhan data [8]. Dari uraian di atas dan beberapa penelitian terdahulu maka bisa dikatakan bahwa dalam pemilihan tipe busi harus 
disesuaikan dengan kebutuhan kerndaraan khususnya roda dua karena berdampak pada kualitas hasil pembakaran. Maka penelitian ini bertujuan untuk mengetahui pengaruh penggunaan tipe busi terhadap kinerja berupa torsi, dan daya efektif pada sepeda motor empat langkah Jupiter MX 135 cc. Adapun dalam pengujian kinerja mesin alat yang digunakan untuk mengukur torsi sebut dynamometer prony brake. Prinsip kerjanya sebuah rotor digerakan oleh mesin dalam melakukan pengujian baik secara mekanik, hidrolik atau elektronik dihubungkan ke sebuah stator. Rotor dan stator yang dimaksud pad motor adalah cakram yang berfungsi sebagai Rotor dan kampas cakram berfungsi sebagai Stator. Selanjutnya Brake Horsepower (BHP) merupakan besaran untuk mengindikasikan Horsepower (Daya) actual yang dihasilkan oleh mesin. BHP biasanya diukur dengan peralatan pengukur daya (Prony Brake) yang ditempatkan pada driveshaft Mesin (Magnet).

\section{BAHAN DAN METODE}

\subsection{Torsi Pada Prony Brake}

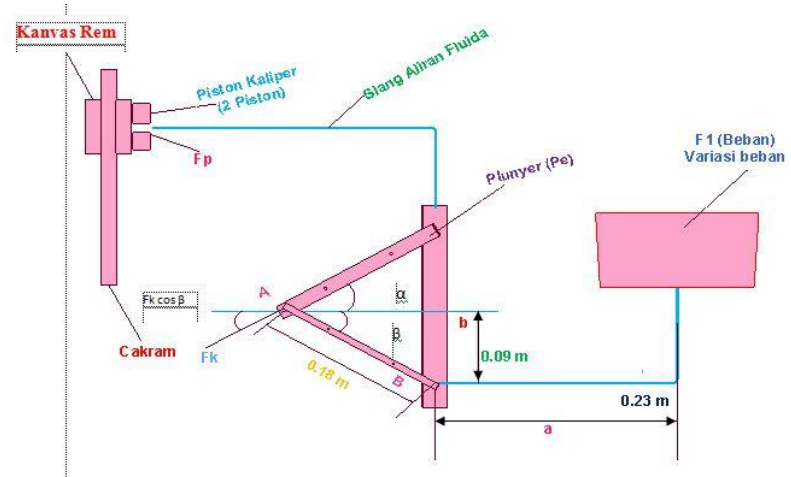

Gambar 1 Mekanisme kerja prony brake

Lengan pedal rem ditumpuh pada titik B (tumpuan rol), sehingga dapat bergerak turun/naik dan kemudian salah satu lengan dari titik B dihubungkan ke pompa hidrolik titik A. Gaya tekan pompa hidrolik didistribusikan oleh beban F1 (yang divariasikan). Berdasarkan gambar maka gaya Fk dicari dengan mengambil momen terhadap titik B.

$$
F_{k}=\frac{F_{1} \cdot a}{b \cos \beta}
$$

Besar tekanan hidrolik Pe dari pompa plunyer dapat dihitung dengan persamaan berikut:

$$
P_{e}=\frac{F}{A}
$$

Selanjutnya akibat tekanan hidrolik, fluida cair ditransfer melalui pipa yang menghubungkan plunyer dan caliper. Pada caliper terdapat piston yang berfungsi untuk menekan kanvas rem. Besar gaya tekan piston pada kanpas rem Fp dapat dihitung sebagai berikut:

$$
F_{p}=\left(P_{e} \times \frac{\pi}{4} \times d_{2}^{2}\right) \times 2
$$
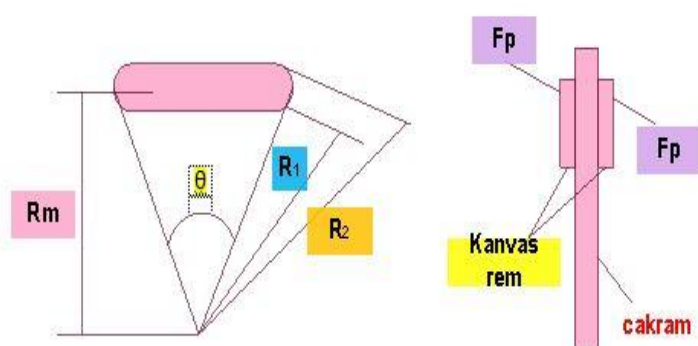

Gambar 2 Kontruksi kanvas cakram

Kanvas rem berada pada dua sisi permukaan piringan cakram, ketika ditekan oleh gaya Fp yang tegak lurus dengan kanvas rem akan menyebabkan kanvas rem dan piringan cakram saling bergesekan sehingga menimbulkan gaya gesek yang bekerja sejajar piring cakram. Ketika piringan cakram diputar dengan putaran tertentu, maka poros akan memberikan usaha yang besar sebagai reaksi untuk melawan gaya gesek. Usaha yang dilakukan ini dalam bentuk momen torsi. Berdasarkan dimensi dari piringan cakram, kedudukan kanvas rem, besar gaya Fp dan koefisien gesek antara kedua permukaan, maka torsi dapat dihitung dengan persamaan sebagai berikut:

$$
T_{p}=2 \cdot \mu \cdot F_{p}\left[\frac{2 \theta}{3 \sin \frac{\theta}{2}} \cdot\left(1-\frac{R_{1} \cdot R_{2}}{\left(R_{1}+R_{2}\right)^{2}}\right] \cdot\left[\frac{R_{1}+R_{2}}{2}\right]\right.
$$

Berdasarkan mekanisme (alat pengujian) yang telah dijelaskan di atas maka torsi pada motor penggerak dapat di hitung sebagai berikut [5]: 


$$
T_{m}=\frac{T_{p}}{\eta_{t o t} \cdot i_{\text {tot }}} \ldots \ldots N \cdot m
$$

Dengan demikian, torsi pada motor dapat dihitung sebagai berikut [6]:

$$
T_{m}=\frac{T_{p}}{0,898 \cdot i_{\text {tot }}} \ldots \ldots N \cdot m
$$

Sedangkan daya efektif motor adalah tenaga yang diberikan oleh motor untuk mengatasi beban torsi pada putaran poros prony brake tertentu, dan dapat dihitung dengan persamaan sebagai berikut [1]

$$
N_{e}=\frac{\pi \cdot n_{1} \cdot T_{m}}{30} \ldots \ldots \text { Watt }
$$

\subsection{Metode Penelitian}

Sebelum melakukan pengujian penulis perlu memperhatikan kesiapan bahan bakar, memeriksa pelumasa mesin, memeriksa kondisi mesin (penyetelan karburator dan pembersihan system bahan bakar dan pengapian) dan menyiapkan alat uji.

Langkah awal mesin dihidupkan selama 5 menit sebagai pemanasan. Dalam kondisi tidak dibebani. Selanjutnya mesin dioperasikan pada Reduction Gear 4, putaran penghantar hingga mencapai 6000 rpm kemudian beban $\left(\mathrm{F}_{1}\right)$ seberat $3 \mathrm{~kg}$ diletakan pada pedal rem dan biarkan kendaraan beroperasi hingga pemakaian bahan bakar mencapai pemakaian $10 \mathrm{ml}$. setelah itu diberi aba-aba untuk memperhatikan angka yang tertera pada kedua Tachometer dan Stopwatch. Dan beban diangkat dari pedal rem. Catat putaran pada poros engkol $\left(\mathrm{n}_{1}\right)$, putaran pada prony brake $\left(\mathrm{n}_{2}\right)$ dan waktu (t) pada tabel penelitian. Kemudian dengan prosedur yang sama tapi ukuran beban berbeda untuk $4 \mathrm{~kg}, 5 \mathrm{~kg}$ dan $6 \mathrm{~kg}$ masih tetap untuk Reduction Gear 4 dan hasil penelitian dimasukan ke tabel. Setelah pengujian Reduction Gear 4 selesai, kendaraan didiamkan hingga dingin. Setelah itu lanjutkan untuk Reduction Gear 3, Reduction Gear 2, dan Reduction Gear 1 dengan prosedur penelitian yang sama.

\section{HASIL DAN PEMBAHASAN}

Mendapatkan Performance sebagaimana diuraikan di atas, maka pertama yang harus dicari adalah besar torsi yang terjadi pada prony brake. Mekanisme kerja prony brake tergambar pada gambar 1, maka parameter utama untuk medapatkan torsi pada prony adalah beban. Melalui alat pendukung, maka dilakukan juga variasi beban yang kemudian dikonversi dari kilogram ke Newton. Dari variasi beban tersebut dihitung gaya pada plunyer $F_{k}$ (Pers. 1), tekanan hidrolik Pe (Pers. 2) dan gaya piston $F_{p}$ (Pers. 3). Besar gaya tekan piston $F_{p}$ serta dimensi dari piringan cakram (gambar 2), maka dapat dihitung besar momen torsi pada poros prony brake dan perhitungan menggunakan persamaan 4 .

Torsi dan Daya efektif motor adalah merupakan performance utama dari suatu kendaraan selain pemakaian/konsumsi bahan bakar. setelah sebelumnya melakukan beberapa perhitungan pendukung sesuai variasi variabel penelitian maka Torsi pada motor dapat dihitung dengan menggunakan persamaan 6. Sedangkan Daya efektif motor dapat dihitung dengan menggunakan persamaan 7. Data yang dibutuhkan untuk menghitung torsi pada motor adalah torsi pada poros prony brake, putaran poros engkol $\left(\mathrm{n}_{1}\right)$ motor dan putaran pada prony brake $\left(\mathrm{n}_{2}\right)$. Data kedua putaran untuk tiap variasi diambil dengan menggunakan tachometer saat dilakukan pengujian. Daya efektif motor dihitung berdasarkan torsi motor yang telah diperoleh dan putaran engkol motor $\left(\mathrm{n}_{1}\right)$.

Gambar 3 merupakan grafik Analisa torsi dan daya untuk gigi 1 pada gambar 3 merupakan grafik variasi beban 29,43 - 58,86N. Busi Standar mempunyai torsi minimum 2,94 N.m pada beban 29,43N dan meningkat sampai 5,09 N.m pada beban $58,86 \mathrm{~N}$. Busi Platinum mempunyai torsi minimum 2,69 $\mathrm{Nm}$ pada beban 29,43 dan meningkat sampai $5,22 \mathrm{Nm}$ pada beban $58,86 \mathrm{~N}$. Hal ini member arti bahwa motor membutuhkan usaha untuk mengatasi gaya gesek pada prony. Pada grafik terlihat gigi 1 pada beban $29,43-49,05 \mathrm{~N}$ putaran dihasilkan oleh busi Platinum lebih tinggi dari busi Standar setelah beban $49,05-58,86 \mathrm{~N}$ berada di bawah busi Standar. 


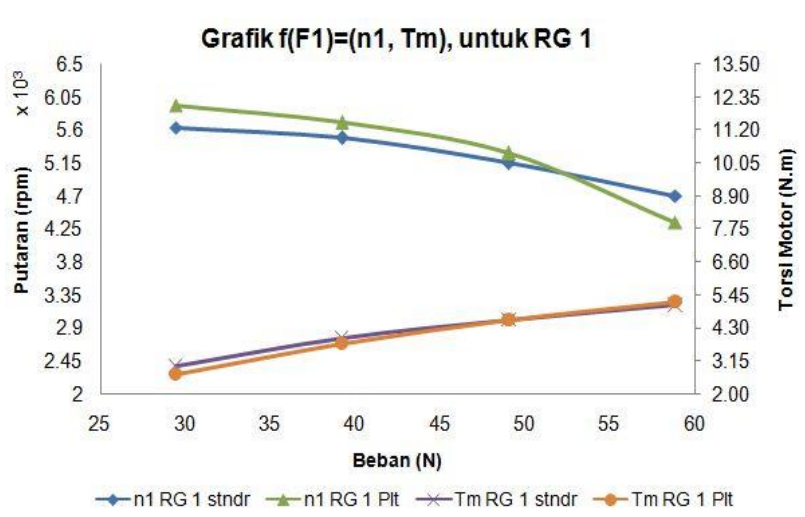

Gambar 3 Grafik fungsi antara putaran, torsi akibat variasi beban pada gigi 1 .

Gambar 4 memperlihatkan daya efektif meningkat untuk busi Platinum pada beban 29,43 $49,05 \mathrm{~N}$ dan cenderung menurun pada beban 49,05$58,86 \mathrm{~N}$. Sedangkan busi Standar terus meningkat dri beban $29,43-58,86 \mathrm{~N}$. Pada beban besar daya efektif busi Platinum mengalami penurunan berbeda dengan busi Standar cenderung stabil.

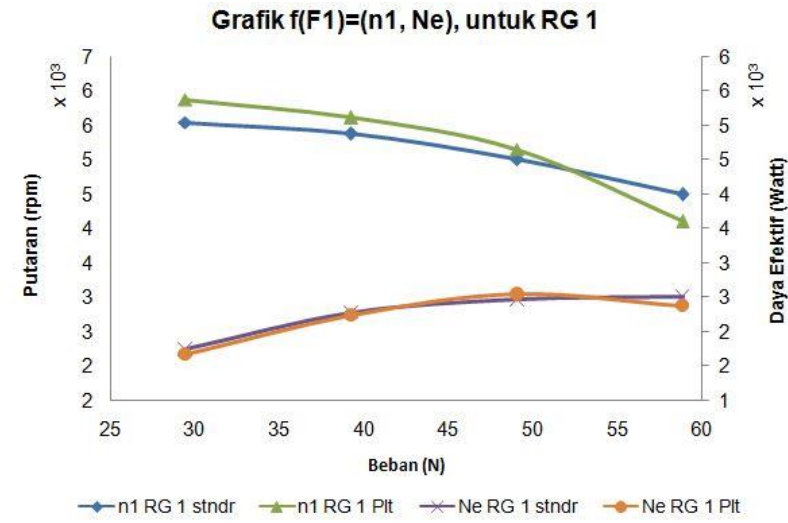

Gambar 4 Grafik fungsi antara putaran dan daya efektif akibat variasi beban, ukuran busi pada gigi 1

Gambar 5 menunjukan daya maksimum didapat pada beban $58,86 \mathrm{~N}$ sebesar $2504,31 \mathrm{~W}$ dan torsi 5,09 $\mathrm{Nm}$ dan merupakan torsi maksimum busi Standar. Daya maksimum sebesar $2541,08 \mathrm{~W}$ pada beban $49,05 \mathrm{~N}$ dan torsi sebesar $4,82 \mathrm{Nm}$ dan torsi maksimum sebesar 5,23Nm untuk busi Platinum.

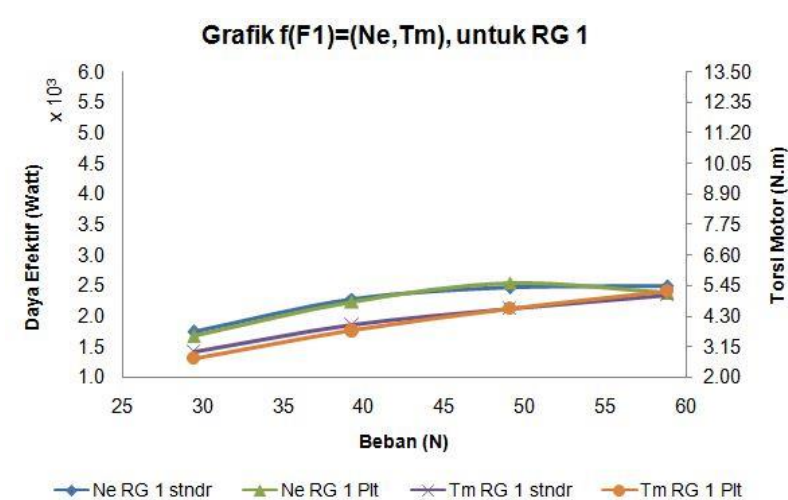

Gambar 5 Grafik fungsi antara putaran, torsi dan daya akibat variasi beban, ukuran busi pada gigi 1 .

Gambar 6 memperlihatkan busi Standar mempunyai torsi minimum $4,80 \mathrm{Nm}$ pada beban $29,43 \mathrm{~N}$ dan meningkat sampai maksimum $8,90 \mathrm{Nm}$ pada beban $58,86 \mathrm{~N}$. untuk bus Platinum torsi minimum sebesar $3,97 \mathrm{Nm}$ dan meningkat sampai maksimum $8,59 \mathrm{Nm}$ pada beban $58,86 \mathrm{~N}$. Peningkatan torsi pada beban yang besar mengartikan bahwa motor membutuhkan usaha yang besar untuk mengatasi gaya gesek.

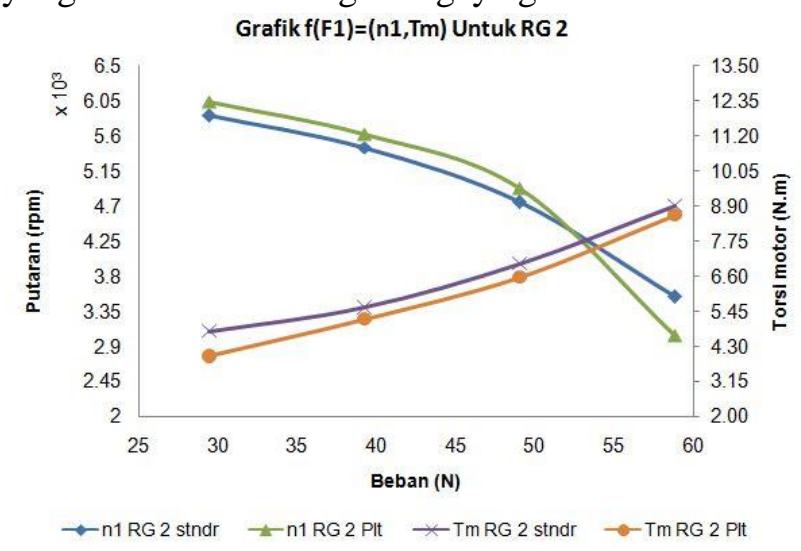

Gambar 6 Grafik fungsi antara putaran \& torsi akibar variasi beban, ukuran busi pada gigi 2

Gambar 7 memperlihatkan daya efektif meningkat untuk busi Platinum dan busi Standar. Pada beban 29,43 - 49,05N dan cenderung turun pada beban $49,05-58,86 \mathrm{~N}$, penurunan terlihat pada busi Platinum. 


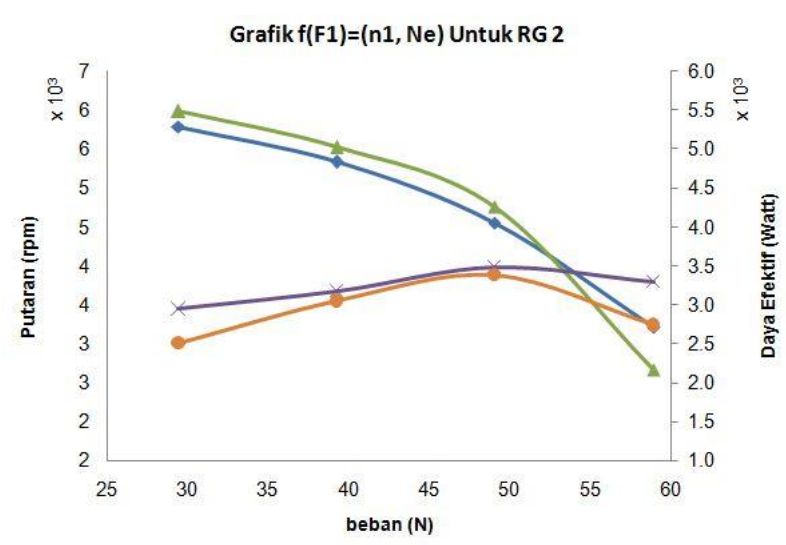

$\rightarrow$ n1 RG 2 stndr $\quad \leadsto$ n1 RG 2 PIt $\quad$-Ne RG 2 stndr $\quad \rightarrow$ Ne RG 2 PIt

Gambar 7 Grafik fungsi antara putaran \& daya akibat variasi beban, ukuran busi pada gigi 2

Gambar 8 memperlihatkan daya maksimum terjadi pada beban $49,05 \mathrm{~N}$ sebesar $3418,81 \mathrm{~W}$ dan torsi $7,00 \mathrm{Nm}$ namun torsi maksimum busi Standar $8,9 \mathrm{Nm}$ pada beban $58,86 \mathrm{~N}$. Untuk busi Platinum daya maksimum sebesar $3384,49 \mathrm{~W}$ pada beban $49,05 \mathrm{~N}$ dan torsinya $6,55 \mathrm{Nm}$ namun torsi maksimumnya $8,59 \mathrm{Nm}$ pada beban $58,86 \mathrm{~N}$.

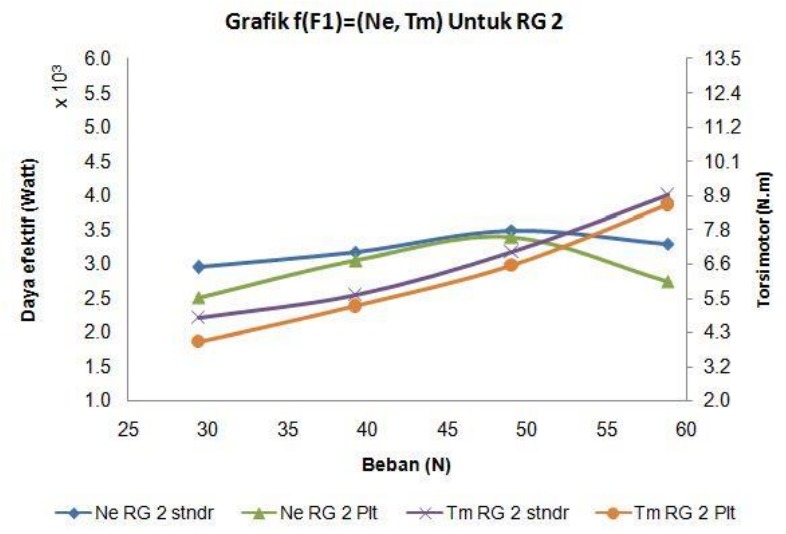

Gambar 8 Grafik fungsi antara putaran, torsi \& daya akibat variasi beban, ukuran busi pada gigi 2

Gambar 9 memperlihatkan busi Standar mempunyai putaran sebesar $5972 \mathrm{rpm}$ pada beban $29,43 \mathrm{~N}$ dan menurun sampai putaran $3201 \mathrm{rpm}$ pada beban $58,86 \mathrm{~N}$. Busi Platinum mempunyai putaran maksimum $5790 \mathrm{rpm}$ pada beban $29,43 \mathrm{~N}$ dan menurun sampai putaran $2854 \mathrm{rpm}$ pada beban $53,95 \mathrm{~N}$. Hal ini terjadi akibat perubahan rasio gigi, meningkatkan putaran pada prony sehingga kebutuhan torsi lebih besar untuk semua variasi beban.

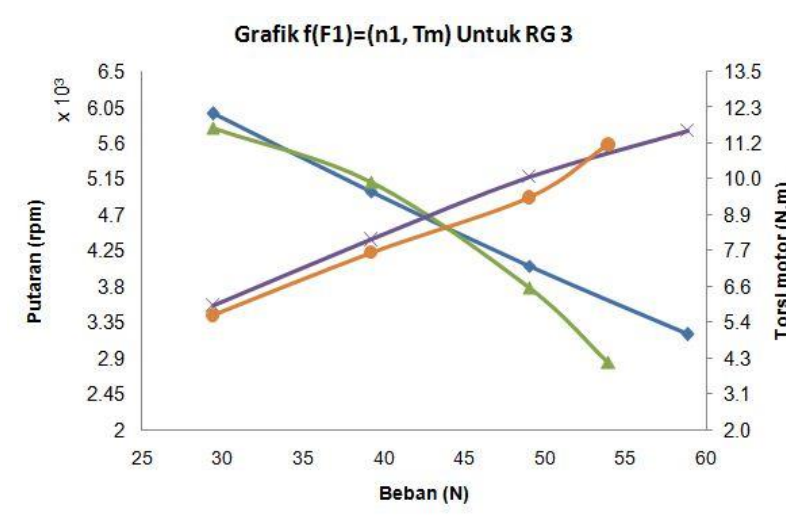

$\leadsto$ n1 RG 3 stndr $\quad ₫$-n1 RG 3 PIt $\quad$-TmRG 3 stndr $\quad \rightarrow$ TmRG 3 PIt

Gambar 9 Grafik fungsi antara putaran \& torsi

akibat variasi beban, ukuran busi pada gigi 3

Gambar 10 memperlihatkan daya meningkat untuk busi Standar pada beban 29,43-49,05N, utk busi Platinum daya meningkat pada beban 29,43 $49,05 \mathrm{~N}$, dan cenderung menurun pada beban 49,05 $-58,86 \mathrm{~N}$ untuk busi Standar. Untuk busi Platinum daya menurun pada beban $49,05-53,95 \mathrm{~N}$.

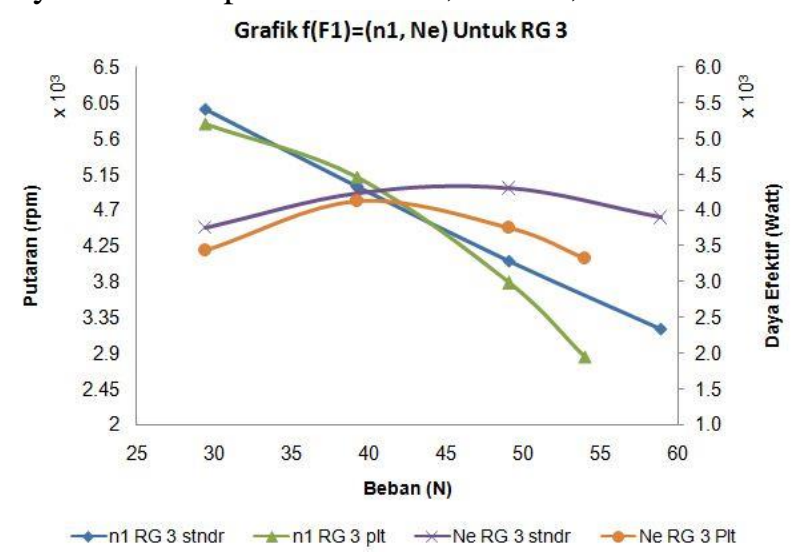

Gambar 10 Grafik fungsi antara putaran \& daya akibat variasi beban, ukuran busi pada gigi 3

Gambar 11 memperlihatkan daya maksimum sebesar $4303,60 \mathrm{~W}$ dan torsi $10,12 \mathrm{Nm}$ pada beban $49,05 \mathrm{~N}$, namun torsi maksimum $11,61 \mathrm{Nm}$ ada beban $58,86 \mathrm{~N}$ untuk busi Standar. Daya maksimum sebesar $4126,27 \mathrm{~W}$ dan torsinya 7,69 $\mathrm{Nm}$ pada beban 39,24 $\mathrm{N}$, namun torsi maksimm $11,14 \mathrm{Nm}$ pada beban 53,95 untuk busi Platinum. 


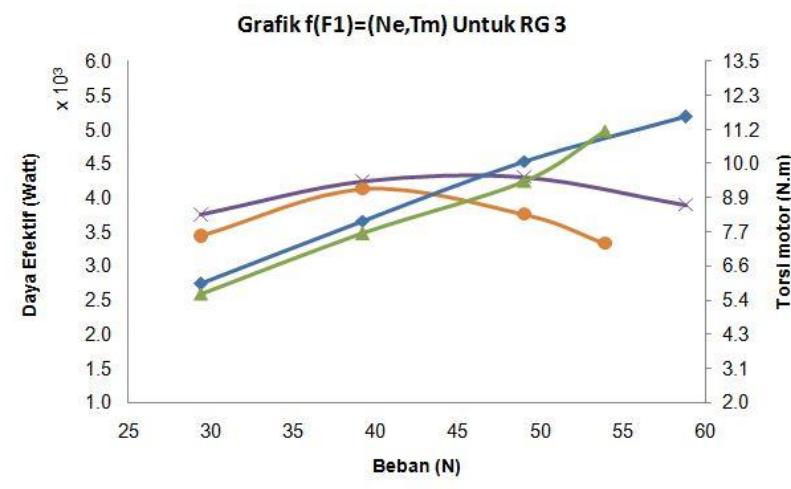

*NeRg 3 stndr $\rightarrow$-Ne RG 3 PIt $\rightarrow$ TmRg 3 stndr $\rightarrow$ Tm RG 3 PIt

Gambar 11 Grafik fungsi antara putaran, torsi

$\&$ daya akibat variasi beban, ukuran busi pada gigi 3

Gambar 12 merupakan grafik variasi beban 29,43 - 58,86N untuk busi Standar dn busi Platinum. Busi Standar menghasilkan putaran maksimum 5977 rpm pada beban 29,43 dan menurun sampai 2440 rpm pada beban $58,86 \mathrm{~N}$. busi Platinum menghasilkan putaran maksimum $5428 \mathrm{rpm}$ pada beban $29,43 \mathrm{~N}$ dan menurun sampai putaran 2167 rpm pada beban $49,05 \mathrm{~N}$. ketika motor dioperasikan pada gigi 4, putaran poros motor meningkat sedangkan putaran poros prony menurun. Kondisi isi terjadi akibat perubahan rasio gigi.



Gambar 12 Grafik fungsi antara putaran \& torsi

akibat variasi beban, ukuran busi pada gigi 4

Gambar 13 memperlihatkan daya meningkat utk busi Standar pada beban 29,43 - 39,24N, sedangkan untuk busi Platinum dayanya meningkat pada beban rendah $24,52 \mathrm{~N}$ dan cenderung turun pada beban $49,05-58,86 \mathrm{~N}$. Untuk busi Standar \& busi Platinum daya cenderung menurun pada beban 29,43 $49,05 \mathrm{~N}$.



Gambar 13 Grafik fungsi antara putaran \& daya akibat variasi beban, ukuran busi pada gigi 4

Gambar 14 memperlihatkan daya maksimum sebesar $5813,11 \mathrm{~W}$ dan torsinya $10,74 \mathrm{Nm}$ pada beban $39,24 \mathrm{~N}$, namun torsi maksimum untuk busi Standar $12,87 \mathrm{Nm}$ pada beban $49,05 \mathrm{~N}$. untuk busi Platinum daya maksimu sebesar 4684,22W dan torsinya $8,24 \mathrm{Nm}$ pada beban $24,52 \mathrm{~N}$, namun torsinya maksimumnya 12,14 pada beban $39,24 \mathrm{~N}$.

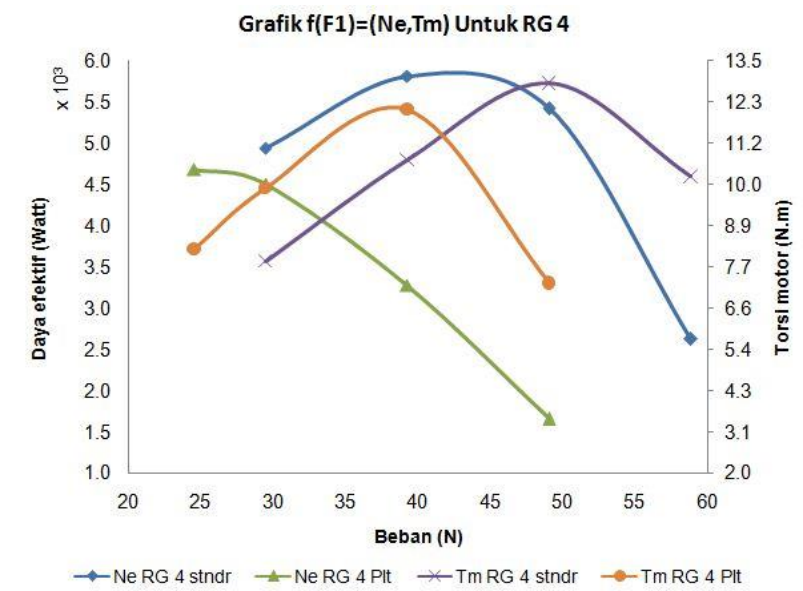

Gambar 14 Grafik fungsi antara putaran, torsi $\&$ daya akibat variasi beban, ukuran busi pada gigi 4

\section{KESIMPULAN}

Berdasarkan hasil pengujian yang telah dikaji sebelumnya, maka dapat disimpulkan bahwa; Putaran meningkat dengan cepat mulai dari gigi 2 sampai gigi 4 dan cenderung stabil untuk busi Platinum jika dibandingkan dengan busi Standar. Namun torsi busi Standar meningkat dari gigi 1 sampai gigi 4 dan cenderung stabil dibandingkan busi Platinum. Artinya bahwa busi Standar dikhususkan untuk pemakaian harian yang mengutamakan daya tampung beban yang lebih 
besar. Sedangkan busi Platinum dikhususkan untuk kendaraan yang mengutamakan kecepatan.

\section{DAFTAR PUSTAKA}

[1] Ansori. A., Pengaruh Variasi Busi Terhadap Emisi Gas Buang Sepeda Motor Empat Langkah. Jurnal : Jurusan Teknik Mesin, Fakultas Teknik, Universitas Negeri Surabaya, 2015.

[2] Aufa. R., Pengaruh Penggunaan Busi Terhadap Konsumsi Bahan Bakar pada Sepeda Motor Honda Beat Tahun 2012. Jurnal : Jurusan Teknik Otomotif, Universitas Negeri Padang, 2015.

[3] Kurniawan. H., Pengaruh Penggunaan Busi Standar, Busi Racing \& Busi Iridium Terhadap Kinerja Mesin Sepeda Motor 4 Langkah 110cc pada Berbagai Tekanan Kompresi. Jurnal : Jurusan Teknik Mesin, Universitas Negeri Semarang, 2016.

[4] Kustiawan. F., Analisa Variasi Busi Terhadap Performa Motor Bensin 4 Langkah. Jurnal : Fakultas Teknik, Universitas Muhammadiyah Surakarta, 2016.

[5] Mustaqin, dan W. Renggani. G., Remapping Pengapian Programable CDI dengan Perubahan Variasi Tahanan Ignition Coil pada Motor Bakar 4 Tak 1225 CC Berbahan Bakar E100. Jurnal :Fakultas Teknik, Universitas Pancasakti. Vol. 12 No. 1 April 2016

[6] Nurdianto. I., Pengaruh Variasi Tingkat Panas Busi Terhadap Performa Mesin Emisi Gas Buang. Jurnal : Fakultas Teknik, Universitas Negeri Surabaya. Vol. 03 No. 03 119-127 2015.

[7] Pasaribu. S., Pengaruh Variasi Celah Busi dan Jenis Busi Terhadap Emisi Gas Buang pada Kendaraan Roda Dua 110CC. Jurnal : Akademi Teknologi Industri Immanuel Medan, Vol. 3 No. 1 Mei 2017.

[8] Putra, T. W., Sudarmo dan W. Yoyok., Pengaruh Jenis Busi Terhadap Konsumsi Bahan Bakar dan Emisi Gas Buang pada Sepeda Motor Honda Revo Fit 110 CC. Jurnal : Fakultas Teknik, Universitas Muhamadiyah Ponorogo. Vol. 5 No. 22016

[9] Rahmadhi. S., Pengaruh Jarak Kerenggangan Celah Elektroda Busi Terhadap Emisi Gas
Buang pada Sepeda Motor 4 Tak. Jurnal : Jurnal Teknik Otomotif, Universitas Negeri Padang, 2015.

[10] Setyono. Dkk., Pengaruh Penggunaan Variasi Elektroda Busi Terhadap Performa Motor Bensin 4 Langkah. Jurnal : Jurusan Teknik Mesin, Institut Sepuluh November, 2015. 